\title{
Jordanian Bengali Pidgin Arabic
}

\author{
Fawwaz Al-Abed Al-Haq, Ibrahim Al-Salman \\ Yarmouk University, Irbid, Jordan
}

\begin{abstract}
This study aims at providing a linguistic description of the JBPA (Jordanian Bengali Pidgin Arabic) which is a variety in use between the Bengali workers and Jordanians who live and work in Al-Hassan Industrial City, Irbid, in the north of Jordan. The primary purpose of this study was to find out whether or not this variety constituted a true pidgin. Data collection was based on interviews with 10 Bengalis. To identify this variety, the author examined it with reference to three linguistic features of the JA (Jordanian Arabic): the phonology, the verbal system, and the negation. The study revealed that the phonology of JBPA was not fully compatible with that of the JA, and that most of the JA sounds tended to change their phonological behavior in the JBPA. In addition, the verb was invariant and simplified; also, the negation in the JBPA was realized by three negative particles: mafîs', 'ma, and 'muŝs'. Finally, the study revealed that the JBPA has the characteristics of a "pre-pidgin" rather than a "stable pidgin".
\end{abstract}

Keywords: Jordanian Pidgin Arabic, Arabic-based pidgins, pidgin Arabic

\section{Introduction}

\section{Jordan at a Glance}

Jordan or "The Hashemite Kingdom of Jordan" is one of the Levantine countries in the Middle East. The official language of Jordan is Arabic. Jordanian Arabic (henceforth, JA) is a dialect of so many dialects in the Levant which includes the dialects of Lebanon, Syria, Jordan, and Palestine (Habash, 2006, pp. 12-15); differences among these dialects, however, are minimal, i.e., linguistic differences are basically found on the phonological and lexical levels. In JA, subdialects also exist; these subdialects are divided into three: UD (urban dialect), RD (rural dialect), and $\mathrm{BD}$ (Bedouin dialect) (for the purpose of this study, the author depended on the RD).

Actually, during the last few decades, several agreements have been held between the Hashemite Kingdom of Jordan and some non-Arabic countries mainly on the level of trade. These agreements have given people from different countries of the world the chance to come to Jordan for work. The continuous flow of many non-Arabic speaking workers into Jordan, in addition to the urgent need to interact with Jordanians on a daily basis and at all places has demanded them to, maybe unconsciously, create a new simplified and reduced variety of JA that can be used as a means of communication when speaking to Jordanians. This article, therefore, attempts to provide a linguistic description of this variety, which the author presumed to be a "pidgin", and which the author called "Jordanian Bengali Pidgin Arabic" (henceforth, JBPA); the article describes the JBPA variety with reference to three linguistic features: (1) the phonology; (2) the verbal system; and (3) the negation. 


\section{Definition of a Pidgin}

Unfortunately, there is no one single definition of "pidgin" approved by scholars. For this study, anyway, the author shall adopt the definition given by Swann, Deumert, Lillis, and Mesthrie (2004) which defines a pidgin as a new and initially simple form of language that arises when two or more groups of people who do not share a common language come into contact with each other. Usually, pidgins evolve from an initial state called "a pre-pidgin" or "jargon" whose grammar is reduced and simplified; the process of forming a pidgin is called "Pidginization".

Usually, there are two or more languages out of which a pidgin is created: One is called the superstrate language whose speakers are powerful in society; the other is the substrate language(s) whose speakers are usually less powerful and who are, in most of the cases, unintelligible by the dominant group (Holm, 2000, p. 5). The superstrate language is believed to be the supplier of the lexicon of the pidgin (therefore, it is called the "lexifier language"). The substrate language, on the other hand, provides the grammar of the pidgin (Swann et al., 2004).

However, as a new generation comes, a pidgin may develop in different ways (e.g., Tok Pisin, Papua New Guinea). In the case where a pidgin is the only common language of a community, "it will be acquired by locally born children and will then become a fully developed language" (Bickerton, 1990, p. 120), leading to the creation of a Creole. The process by which a pidgin develops into a Creole is called "creolization"; this process includes the extension of the pidgin's grammatical and lexical inventory to serve in all the domains of life and to become an official language. Hall (1966, p. 126) argued that pidgins have a "life-cycle" where they are created in a specific situation for an emergent need, and die out soon after the need for them has been fulfilled.

In fact, there are some characteristics that distinguish pidgins from other "normal languages". For example, pidgins lack grammatical complexity and have limited lexical stock; besides, pidgins lack copulas, have a constrained number of appositions and have no sentential embedding (Hymes, 1971, pp. 65-90). Moreover, reduction of the lexicon, unmarkedness of gender, case, number, and tense are of the main characteristics of pidgins (McMahon, 1994, pp. 258-259). Pidgins also lack stylistic options, puns, and metaphors, and have few sociolinguistic markers, such as politeness phenomena (McMahon, 1994, pp. 258-259). On the level of phonology, the consonant inventory in pidgins is usually reduced. Similarly, vowels are usually fewer than their lexifier counterparts, and length distinction is lost (McMahon, 1994, p. 260).

\section{FT (Foreigner Talk)}

FT, a term coined by Ferguson (1971), supposes that the similarities among PCs (pidgins and creoles) are due to the simplification on the part of the target (superstrate) language speakers as a way to communicate with the non-native speakers of their language. Actually, the social gap is much relevant to this context. Valdman (1981) argued that "the use of FT signals to foreigners that they are unwanted guests whose acculturation to the host community is not desired" (p. 43). In fact, Ferguson argued that FT helps in the formation of the so-called "a pre-pidgin".

In much the same way is the baby-talk theory, a theory coined by Bloomfield (1933), which refers to "the simplified language used by adults in order to communicate with children" (Vicente, 2007, p. 18).

\section{Previous Related Studies}

In this part of the paper, the author has discussed two types of pidgin studies: Arabic-based pidgins and English-based pidgins. 
Arabic-based pidgins. One of the studies on Arabic-based pidgins is Smart's (1990) of the Gulf Pidgin Arabic (henceforth, GPA). Smart studied the GPA to find out if this variety can really be classified as a pidgin. He based his study on some cartoon captions in Gulf newspapers in which Arab journalists imitate the language of the workers. Smart divided the GPA verb into three types: the Y(v) - prefixed type, the unstable type, and the imprefixed type. He also claimed that $f i$ in GPA is used as a copula. Smart stated that GPA speakers use the Gulf Arabic particles to negate nouns and adjectives with $m \bar{u} / m u b$ and verbs with $m a$.

Another study on Arabic-lexified pidgins is the one conducted by Tosco (1995) in which he examined the verbal system in JA (Juba Arabic). He concluded that JA speakers use three basic verbal markers: kan, bi (marks the future, eventuality, and conditionality), and ge (conveys the meaning of continuative and habitual meaning), adding that kan is assigned to the non-core markers, while the last two are assigned to the role of core verbal markers.

Tosco also proposed that JA imperative verbs are distinguished from the declarative ones in terms of intonation, and that the negative imperative takes the person marker $t a$ for singular and takum for plural and that both come after the negation.

Bakir (2010) also studied the verbal system in GPA. His material included some data collected by conducting interviews with some Asian expatriates whose native languages are non-Arabic. He concluded that the verb in GPA is unmarked for tense, person, aspect, gender, and number, and that only one form is used to indicate difference in tense, aspect, mood, and voice. He claimed that the common verb used in GPA is the 3rd singular masculine imperfect form: yi ǰi "come", yabi "want" (with a variant yibga), and yaakid "take", being used for first person, second person singular masculine, and feminine, and third person plural subjects in addition to different references to past and future; he added that tense can only be inferred from context or by the existence of some adverbs of time; here are some examples (see Examples (1)-(2)):

Example (1) ?anaa yabi...

1SG want

"I want..."

Example (2) baačir Panaa yabi...

tomorrow 1SG want

"Tomorrow, I want..."

Bakir (2010) also stated that aspect markers are absent, and that GPA speakers use $f i$ to make a progressive verb. Modality, Bakir adds, is expressed by the auxiliaries lāzim (used for necessity and obligation), and mumkin (used for possibility), whereas futurity is indicated by the modal "rūh". Regarding the negation system in GPA, Bakir concludesd that the particle "māfî" is used to negate "existential and equational sentences", and the sentences with main verbs (see Example (3)):

Example (3) Pana māfì nōm

1SG. NEG. sleep

"I don't sleep"

Avram (2010) described a pidginized variety of Arabic used by Romanian and Arab oil workers in Iraq, which he calls "Romanian Pidgin Arabic" (henceforth, RPA). He collected his data by recording some speeches during his fieldwork in Kut (Eastern Iraq) and Rashdiya (north of Baghdad), and by conducting some interviews. On the level of phonology, Avram (2010) claimed that the velar voiceless fricative $/ \mathrm{h} /$ is replaced by $/ \mathrm{h} / \mathrm{in}$ 
word-initial position, and by $/ \mathrm{h} /, / \mathrm{a} /$, or $\varnothing$ in a word final position; besides, the pharyngeal voiceless fricative $/ \mathrm{x} /$ is replaced by $/ \mathrm{h} /$, whereas the voiced velar fricative $/ \mathrm{g} /$ is realized as $/ \mathrm{g} /$, and the emphatic sounds are replaced by their non-emphatic counterparts. The verbal system, Avram concludesd, is invariant in form in RPA, and tense, aspect markers and the copula are absent in RPA.

Næss (2008) tried to explore the linguistic features of GPA in order to find out whether or not the GPA constitutes a "true pidgin", or is just considered as "an individual strategy" used by Asian immigrant workers in order to ease the process of communication (interlanguage).

In his study, Næss (2008) concluded that the basic phonetic inventory in GPA is reduced compared to that of the Gulf Arabic (29 consonants are reduced into 18, and distinction in vowel length is absent).

With reference to the GPA negation system, Næss (2008) argued that two negative markers are used: "ma", used in front of verbs as well as in front of the expletive $f i$; and the particle "mafi", used for non-verbal negation as well as for imperative verbs. Here are some examples:

Example of the negation of non-imperative verbs includes (see Example (4)):

Example (4) bādēn ana gūl hāda bāba, ana ma tibba istogol then 1SG say DEM boss 1SG NEG want work

"Then I told my boss that I wanted to quit"

Another example that explains negation of adjectives is the following (see Example (5)):

Example (5) minni mafi tamām

here NEG nice

"This place isn't nice"

Considering the verbal system, Næss (2008) concluded that it is simplified, and that tense is implicit or marked by adverbs. He also said that $f i$ is used as a progressive aspect marker. He added, "the light verb sawwi is common in the variety, and can be used to form compound verbs with nouns and adjectives" (p. 93).

English-based pidgins. Leechman and Hall (1955) examined the American Indian Pidgin English (henceforth, AIPE), a variety used between Indians and the whites. They provide attestations of the AIPE from various sources in which the whites use a pidginized variety of English in speaking with Indians, and try to analyze its grammatical features. However, their study is only concerned with the linguistic features of the non StdE (Standard English). Some of the grammatical features of the AIPE they provide include the replacement of fricatives by stops, the use of a single verb form derived from the English verb form, and the equational predicate. Here are two examples (see Examples (6)-(7)):

Example (6) "you be de white man, you have soul; when we die we fling in water, big fish come carry us to an oder place, den we live dare and die agen, and... oder place"

Example (7) "Man, brave man, no cheat Indian. Indian no cheat white man"

In conclusion, Leechman and Hall (1955) stressed that AIPE, like any other English-based pidgin, basically presents the features of linguistic reduction and restructuring.

For the GhPE (Ghanaian Pidgin English), Huber (1999) tried to provide an outline of the grammar of the variety used by the uneducated group in Ghana, as opposed to the educated one. He based his description on data collected during field trips to Ghana in 1995, 1996, and 1999. His data consists of about 30 hour recorded speeches from different substrate languages, such as English (de facto), Akan, Dangme, Nzema, Gonja, etc. 
Regarding the GhPE's phonology, /v/ is more or less consistently substituted by /b/ or /f/ in GhPE; also, the approximants [1] and [r] are in free variation in the major Ghanaian substrate languages. Vowels with regard to /i/ and /u/ are not distinctive.

Huber (1999), in addition, provided an overview of the tense/aspect and mood of the GhPE. For the tense/aspect, he presented five forms: zero, dè (Progressive/habitual), kam (sequential tense), bigin (dè) (ingressive), and finiš (completive). For the mood, he provided four forms: gò (future/ conditional), fit (ability/ permission), fò (deontic modality), and wan (intentionalis), proposing that tense/aspect and mood can be put together forming complex structures such as "futureability/permission" (e.g., gō fit). Regarding verbal negation, Huber (1999) stated that it is expressed by no, which takes the first position in the verb phrase, before the mood/aspect markers.

He concluded that this variety can be considered a specific GhPE that is complex and similar to other WAPEs (West African pidgins of English).

Roberts and Bresnan (2008) conducted a study on the retained inflectional morphology in pidgins. Their study includes 29 languages that are either pidgins or were pidgins in their early stages. Actually, they claimed that the loss of inflectional morphology in pidgins could be partial rather than total; i.e., lexifier inflections instead follow a continuum of reduction: full retention-partial retention - partial lexicalization—full lexicalization - full loss, where the first two are considered retentions in their study, whereas the other outcomes result in substantial loss of semantic content. Additionally, they stressed that the process of inflectional simplification or reduction are strategies used to give an explanation to the difficulties of learning a new language for the purpose of saving time and effort.

Siegel (2009) studied the CPE (Chinese Pidgin English) in Australia by collecting his data from a 70-page notebook written in English in the ninth century by a Chinese gold miner. He introduced some morphological features found in CPE, such as go (auxiliary), got (possessive or existential marker), man (pronominal suffix), no (preverbal negative marker). An example on got where it is used as an existential marker is Example (8):

Example (8) got Chinaman river edge walk

"There's a Chineseman walking along the river's edge"

Akande (2010) also investigated the verb phrase in the NPE (Nigerian Pidgin English). He attempted to find out whether or not this variety is a pidgin that is separate from English. He collected his data from some recorded interviews with 30 Nigerian University Graduates from three ethnolinguistic regions; he gave them 36 prompt sentences. Actually, Akande distinguishes between NPE and StdE on the basis of the complex verb phrases used in them, and summarized that the NPE is a distinct variety that has its independent structures, mentioning that only a few similarities exist between the varieties in comparison.

\section{Methods and Procedures}

\section{Population of the Study}

The population of the study consisted of the Bengali workers in Al-Hassan Industrial City in Irbid in the north of Jordan. Most, if not all, of those Bengali workers live in Ar-Ramtha district in the north of Jordan. The estimated total number of Bengalis in Al-Hassan Industrial City was 250. 


\section{Sample of the Study}

The sample of the study included 10 participants, all of whom were males. The reason why women were not considered in this study is that my access to them was not possible. The participants' level of education was elementary, except for one who was an engineer. The subjects' ages ranged between 23 to 44 , while their stays in Jordan ranged between three to eight years.

\section{Data Collection}

The author collected data by recording interviews with Bengalis workers in Al-Hassan Industrial City in Irbid. The author used an advanced mobile phone which was tested before conducting each interview to ensure its voice quality. In fact, to make sure that no interruption or noise of any sort was made, the author preferred to make the interviews at the subjects' living places in Ar-Ramtha district (only two were interviewed at the workplace).

To gather the data, the author developed a list of personal questions which the author asked to the subjects. The recorded data was about four-hour long. For ethicality, the author made sure to inform each participant of the nature of my project, and then asking them if they wanted to participate in this project by conducting interviews in JA variety as being recorded.

\section{Data Analysis}

Actually, the author based his analysis on the interviews' recordings' transcripts. The data collected from the recorded interviews was analyzed and described in terms of phonology, negation, and the verbal system. The method the author used in analyzing the data was the qualitative method which is a descriptive method rather than statistical.

\section{Discussion and Findings}

The following description of the JBPA is based on Næss (2008).

\section{Phonology}

The phonology of JA. Consonants. There are 29 consonants in JA. Table 1, which is a modified version of the one given by Næss (2008, p. 28), illustrates these consonants.

Table 1

JA Consonants

\begin{tabular}{|c|c|c|c|c|c|c|c|c|c|c|c|c|}
\hline & & Bilabial & $\begin{array}{l}\begin{array}{l}\text { Labio-d } \\
\text { ental }\end{array} \\
\end{array}$ & \begin{tabular}{|l|} 
Inter-de \\
ntal
\end{tabular} & \begin{tabular}{|l}
$\begin{array}{l}\text { Interdental } \\
\text { emphatic }\end{array}$ \\
\end{tabular} & Alveolar & $\begin{array}{l}\text { Alveolar } \\
\text { emphatic }\end{array}$ & \begin{tabular}{|l|}
$\begin{array}{l}\text { Pal-ata } \\
\text { ls }\end{array}$ \\
\end{tabular} & Velar & Uvular & \begin{tabular}{|l|}
$\begin{array}{l}\text { Phary-n } \\
\text { geal }\end{array}$ \\
\end{tabular} & Glottal \\
\hline Stops & $\begin{array}{l}\text { VL } \\
\text { VD }\end{array}$ & $\mathrm{b}$ & & & & $\mathrm{t}$ & ț & & $\begin{array}{l}\mathrm{k} \\
\mathrm{q} g \\
\end{array}$ & & & ? \\
\hline Fricatives & $\begin{array}{l}\mathrm{VL} \\
\mathrm{VD}\end{array}$ & & $\mathrm{f}$ & $\begin{array}{l}\Theta \\
\partial\end{array}$ & dִ & $\begin{array}{l}\mathrm{s} \\
\mathrm{z}\end{array}$ & ș & $\check{s}$ & & $\begin{array}{l}\mathrm{x} \\
\dot{\mathrm{g}}\end{array}$ & $\begin{array}{l}h \\
\dot{q}\end{array}$ & h \\
\hline Affricates & \begin{tabular}{|l|}
$\mathrm{VL}$ \\
$\mathrm{VD}$
\end{tabular} & & & & & & & $\begin{array}{l}\mathrm{c} \\
\mathrm{j} 3\end{array}$ & & & & \\
\hline Nasals & VD & $\mathrm{m}$ & & & & $\mathrm{n}$ & & & & & & \\
\hline Tap & VD & & & & & $\mathrm{r}$ & & & & & & \\
\hline $\begin{array}{l}\text { Approxi- } \\
\text { mants }\end{array}$ & VD & & & & & 1 & & j & w & & & \\
\hline
\end{tabular}


The speakers of JA use these sounds in spoken,written and even Standard Arabic. However, phonological variation among Jordanian dialects does exist. For example, in the UD the velar voiceless stop $/ \mathrm{k} /$ is usually replaced by /č/. Additionally, the voiceless stop/g/is sometimes substituted with the glottal stop/ $/$ / in the UD (e.g., "galam" "pen" becomes Palam); besides, the interdental voiced fricative / $/$ / is pronounced as /d / in the RD and as /d/ in the UD in some words (e.g., hāð a "this" becomes hāḍa in RD; and hada in UD); also, the glottal stop /r/ as /î/ in a word-medial position in all Levantine vernaculars (e.g., bi is "wall" becomes bēr) (SawāCi, 2009, p. 6).

Vowels. There are 10 vowels in JA, which can be seen in Table 2.

Table 2

JA Short and Long Vowels

\begin{tabular}{|c|c|c|c|c|}
\hline & & Front & Central & Back \\
\hline High & $\begin{array}{l}\text { Short } \\
\text { Long }\end{array}$ & $\begin{array}{l}\text { i (mil saga “spoon") } \\
\overline{1} \text { (ba } \overline{1} \mathrm{id} \text { "distant") }\end{array}$ & & $\begin{array}{l}\text { u (suPāal “question”) } \\
\overline{\mathrm{u}} \text { (maqbūl "acceptable") }\end{array}$ \\
\hline Mid & $\begin{array}{l}\text { Short } \\
\text { Long }\end{array}$ & $\begin{array}{l}\text { e (inte "you") } \\
\bar{e} \text { (bēt "house") } \\
\end{array}$ & & $\overline{\mathrm{o}}$ (lōn “colour”) \\
\hline Low & $\begin{array}{l}\text { Short } \\
\text { Long }\end{array}$ & $\bar{a}$ (bāb 'door') & $\begin{array}{l}\text { a (maktab "office") } \\
\text { a: (ra:ḥ "went") }\end{array}$ & \\
\hline
\end{tabular}

The phonology in JBPA. The consonants. The stops. JA shares five stops with JBPA: /b/, /t/, /d/,/k/, and/g/. Actually, the unvoiced velar $/ \mathrm{k} /$ seems to have undertaken a shift into /g/ in the JBPA. Example (9) illustrates this:

Example (9) ?ana sā tamanya izi hōn, ana sagin fi Ramta

1st SG o'clock eight come here, 1st SG live in Ramta.

"I live in Ramtha; I come here at eight o'clock"

Context: The participant is asked "what time do you come to work?"

Moreover, the JBPA speakers, in most of the contexts, realized the glottal stop / $/$ / either as a long vowel [ $\tilde{\mathrm{v}}]$ or sometimes never preserved it as in Example (10):

Example (10) Pinta gadēs ümur fī

2ndSG. Q. age COP.

"How old are you?"

Context: The participant asked the researcher "How old are you?"

Like the other Arabic emphatic sounds, the emphatic alveolar stop /ț/ was absent in the JBPA; the JBPA speakers replaced it with its non-emphatic counterpart/t/. Example (11) explains this phonological change:

Example (11) ātini maj

\section{IMP-Give water}

"Give me some water"

Context: Participant was asked "How do you ask somebody for water?"

Fricatives. Labiodental fricatives. In fact, the author has noticed that the JBPA speakers would replace the unvoiced labiodental fricative /f/ with the unvoiced stop /p/ (see Example (12)).

Example (12) Șaddah byārap yilāb ?ana

Cards know play1st SG

"I know how to play cards"

Context: The participant was asked "Do you know how to play cards?" 
Interdental fricatives. The JA interdental fricatives $/ \Theta /$ and $/ \delta /$ were not preserved in the JBPA. The

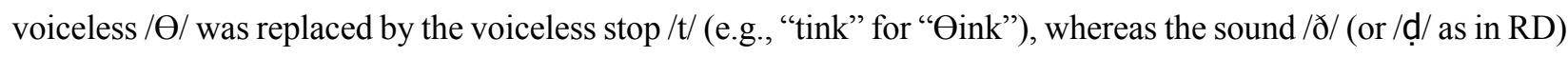
was realized as /d/ (this is a feature of the UD). In fact, Kachru (2006, p. 31) generalized that, in Hindi, the interdental fricatives are pronounced as dental plosives in the borrowed words of English. The author thinks that this can also be the case for Bengalis when they come to use Arabic, since Bengali and Hindi are much similar; examples $3 \mathrm{a}$ and $3 \mathrm{~b}$ below give more details:

Example (13) ?ani sagin fi Ramta

1st SG live in Ramtha

"I live in Ramtha"

Context: The participant was asked "Where do you live?"

Example (14) fi rus, fi bandōra fi hada samag kullu iš fi ōn

EXPL. rice, EXPL. tomato, EXPL. DEM fish everything EXPL. here

"There is everything here: rice, fish and tomato"

Context: The participant was asked "What type of food do you have at you living place?"

Alveolar fricatives. Regarding the voiced fricative / $\mathrm{z} /$, the participants sometimes realized it as $/ \mathrm{s} /$; here is an example (see Example (15)):

Example (15) ?ani bišūp bas tilivisyōn

1 st SG see only television

"I see in television"

Context: the participant was asked "How do you spend your free time?"

Uvular fricatives. The JA velar fricatives are the voiced $/ \dot{\mathrm{g}} /$ and the voiceless $/ \mathrm{x} /$. The speakers of the JBPA would make a shift from $/ \dot{\mathrm{g}} /$ into $/ \mathrm{k} /$ or $/ \mathrm{g} /$, and from $/ \mathrm{x} /$ into $/ \mathrm{k} /$; examples on the two cases are the following (see Examples (16)-(17)).

Example (16) Pani ōn fi sukul

1st SG here COP. work

"I work here"

Context: The participant is asked "Why are you in Jordan?"

Example (17) Pana hōn tamān sanāt kamsa sār

1 st SG. here eight years five month

"Eight years and five months"

Context: the participant is asked "How long have you been in Jordan?"

The pharyngeal fricatives. The pharyngeal /h/ never appeared in the recorded material; instead, the participants pronounced it either as a "slight" /h/ or as a long vowel [ $\tilde{\mathrm{v}}]$. Actually, the author has noticed that this sound (also the other Arabic emphatic sounds) is absent in the consonant inventory of the Bengali language. Therefore, it was typical for the JBPA speakers not to preserve it in their speeches. Example (18) explains how the pharyngeal /has wost.

Example (18) hassa fi wād māgina karbān ?ana bisallih

Now EXPL. one machine broken down 1st SG might fix

"If one machine is broken down, I fix it" 
Context: The participant is asked "What is your main role in the factory?"

Similarly, its voiced counterpart/G/ was absent in the JBPA; it was sometimes pronounced as $/ \mathrm{P} / \mathrm{and}$ in most

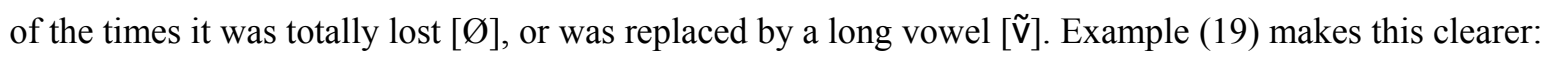

Example (19) hada momgin finišs, $b \bar{a} d u$ sawwi zadīd hada mudīr huwe yedfã kullu

this. might. finish, then make new this manager 3rd SG. M pay all

"This might finish, then the manager renews it for me"

Context: Participant is asked "What do you do when your visa finishes?"

Alveolar emphatic fricative. The alveolar emphatic fricative /ș/ was realized as /s/ by the JBPA speakers (see Examples (20)-(21)).

Example (20) ?ana fi talata sadīg ōn

1st SG EXPL three friend here

"There are three friends here"

Context: The participant is asked "How many persons do you have in your room?"

Example (21) ana taglīp wa magas

1 st SG packaging and scissors

"I do the packing and the cutting"

Context: Participant is asked "What do you do in the factory?"

Affricates. The palatal affricate $/ \bar{j} /$ was frequently substituted with the voiced alveolar $/ z /$, and only few speakers seemed to maintain it; Example (22) clarifies this:

Example (22) nafarat bangāali kullu bizi tyārah

people Bengali all come plane

"He and I come by plane"

Context: The participant is asked "How do Bengalis come to Jordan?"

Tap. The author has noticed that in some cases the tap /r/ was pronounced as a /1/. Example (23) shows this shift: Example (23) Pana bilūh balad kullu talāta sana

1st SG go country all three year

"I return to my country every three years"

Context: the participant is asked "How often do you visit your country?"

Table 3

A Descriptive Table of the JBPA Consonants

\begin{tabular}{|c|c|c|c|c|c|c|c|c|c|c|c|c|}
\hline & & Bilabial & $\begin{array}{l}\text { Labio-de } \\
\text { ntals }\end{array}$ & \begin{tabular}{|l|}
$\begin{array}{l}\text { Inter-de } \\
\text { ntal }\end{array}$ \\
\end{tabular} & $\begin{array}{l}\text { Interdental } \\
\text { emphatic }\end{array}$ & $\begin{array}{l}\text { Alveolar } \\
\text { emphatic }\end{array}$ & Alveolar & \begin{tabular}{|l} 
Pala-tal \\
s
\end{tabular} & Velar & Uvular & \begin{tabular}{|l|} 
Phary-ng \\
eal
\end{tabular} & Glottal \\
\hline Stops & $\begin{array}{l}\mathrm{VL} \\
\mathrm{VD} \\
\end{array}$ & $\mathrm{b}$ & & & & $\mathrm{t}(\mathrm{t})$ & $\mathrm{t}$ & & k & & & 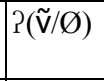 \\
\hline Fricatives & $\begin{array}{l}\text { VL } \\
\text { VD }\end{array}$ & & $f(p)$ & $\begin{array}{l}\Theta(t) \\
\partial(d)\end{array}$ & det(d) & $s+(s)$ & $\begin{array}{l}\mathrm{s} \\
\mathrm{z}\end{array}$ & $\begin{array}{l}\text { šs } \\
3\end{array}$ & & $\begin{array}{l}\mathrm{x}(\mathrm{k}) \\
\dot{\mathrm{g}}(\mathrm{g}, \mathrm{k})\end{array}$ & \begin{tabular}{|l|}
$\mid \mathrm{h}(\mathrm{h})$ \\
$\dot{\mathrm{C}}(\tilde{\mathrm{v}} / \varnothing)$
\end{tabular} & $\mathrm{h}$ \\
\hline Affricates & $\begin{array}{l}\mathrm{VL} \\
\mathrm{VD} \\
\end{array}$ & & & & & & & 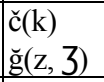 & & & & \\
\hline Nasals & VD & $\mathrm{m}$ & & & & & $\mathrm{n}$ & & & & & \\
\hline Tap & VD & & & & & & $\mathrm{r}(\mathrm{l})$ & & & & & \\
\hline $\begin{array}{l}\text { Approxi- } \\
\text { mants }\end{array}$ & VD & $\mathrm{w}$ & & & & & 1 & $\mathrm{y}$ & w & & & \\
\hline
\end{tabular}


Table 3 shows a basic description of the JBPA consonants, which is a modified version of the one given by Næss (2008, p. 43). The possible substitutions of some sounds are bracketed next to them.

\section{Verb Phrase and Negation}

Arabic sentences can be divided "into verbal sentences (containing a verb) and non-verbal sentences (containing no verb)" (Aziz, 1989, p. 11). This part will be concerned with the two types.

Verb phrase and negation in JA. Verbal sentences and negation in JA. In Arabic, the verb is of two forms: past/perfect and present/imperfect. The Arabic tense/aspect refers to a repeated action, a fact, or ability in the present. In addition, the past/perfect aspect refers to actions, situations before the present. Both past/perfect and imperfect verbs are inflected for tense, person, gender and number. The prefix $b$ - is the present/imperfect marker. Tables 4 and 5 illustrate more (Cantineau, 1946, p. 214).

Table 4

JA Imperfect Tense

\begin{tabular}{|l|l|l|}
\hline & Singular & Plural \\
\hline 3rd masc. & buktub & buktubu \\
\hline 3rd fem. & btuktub & buktubin \\
\hline 2nd masc. & btoktub & btuktubu \\
\hline 2nd fem. & btuktubi & btuktubin \\
\hline 1 st com. & baktub & bnuktub \\
\hline
\end{tabular}

As can be seen in Table 4, the suffix $b$ - is added to all the verbs to indicate the imperfect. Table 5 , on the other hand, displays the structure of the perfect verbs in JA.

Table 5

JA Perfect Tense

\begin{tabular}{|l|l|l|}
\hline Personal Pron. & Singular & Plural \\
\hline 3rd masc. & katab & katabu \\
\hline 3rd fem. & katbat & katabin \\
\hline 2nd masc. & katabit & katabtu \\
\hline 2nd fem. & katabti & katabtin \\
\hline 1st com. & katabit & katabna \\
\hline
\end{tabular}

To negate the perfect and imperfect verbs, the negative particle $m \bar{a}$ is inserted immediately before them, and the RD optional morpheme $-s ̌$ is suffixed to the verb, making the split-morpheme $m \bar{a} . . . \check{s}$ (Cantineau, 1946, p. 390; SawāYi, 2009, p. 40; Palva, 2004, p. 229). Example (24) shows how the imperfect verb in JA is negated:

Example (24) ?ani mā bašrab (iš)...

1st SG. NEG. drink-1st SG.M.IPF.

"I don't drink..."

An example on the JA perfect verbs is given in Example (25):

Example (25) hī mā širbat (ǐ̌)

3rd SG. F. NEG. drank-3rd SG.F.PER.

"She didn't drink"

To express the present progressive aspect, the auxiliary verb ga $\bar{a}$ sid is placed before the main verb: ?ani gā Sid 


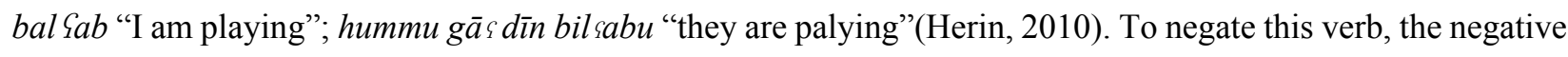
marker miš is added; hence, Pani miš gã sid bal sab "I am not playing"; and hummu miš gā sdīn bil sabu "they are not playing". For the past progressive, the copula kān + "was" is placed immediately before verbs. The negation of this helping verb is realized by $m \bar{a}$.

Futurity in JA is expressed by the prefix $b$-, too. Herin (2010) claimed that this prefix is a polyfunctional morpheme used to denote progressive present or future: batgadda sindak yōm il J̆um sah "I will have lunch at your place on Friday". Moreover, the pseudo-verb bidd + expresses futurity in all Levantine dialects (Vanhove, Miller, \& Caubet, 2009, p. 347), and takes its form from the subject pronoun; this verb is negated by $m \bar{a}$. Examples (26)-(28) explain this:

Example (26) Pani biddi Paḥči macak kilimtēn

1SG. will say.IPF with-2SG two-words

"I will tell you a few words"

Example (27) hì bidha tīji

3sg. F will. come.IPF

"she will to come"

Example (28) Ri hnna mā bidna nīji

1pl. won't come.IPF

"We won't come"

With reference to the imperatives, they are "formed from the non-past, and always have the long vowel of the non-past" (McLoughlin, 1982, p. 47). They are used only with 2nd person, and are inflected for gender and number; thus, for 2nd sg. M. we say Pišrub "(you) drink"; and for 2nd pl. M., we say Pišrubu "(you) drink"; also, we say Pišrubi "(you) drink" for 2nd sg. F. and Pišrabn "(you drink)" for 3rd pl. F.

To negate the imperative verbs in JA, the negation marker $l \bar{a}$ plus the prefix $t$ - (prefixed to the imperative verb) are added (Palva, 2004; Sawā̧i, 2009); thus; lā tišrabi and lā tišrab are examples on the negation of the imperative verbs.

Considering the modality in JA, the modal verb lāzim is used to express obligation and necessity. Examples (29)-(30) explain this:

Example (29) (you) lāzim tiskut [obligation]

(you) TMA. shut up

"you must keep silent"

Example (30) Pinte lāzim tšūf il-dactōr [necessity]

2nd SG.M TMA. see the-doctor

"You should see a doctor"

Furthermore, the JA makes use of the modal verb momkin "may" or "might" to express permission and possibility: Pinta momkin trūh "you may go" (indicating permission) and Pana momkin Pāju "I might come" (indicating possibility). To indicate ability, the JA speakers use b-agdar "can" (also used for permission).

With reference to the existential construction, JA uses the expletive $f i$ as in Examples (31)-(32):

Example (31) fi maldga? taḥt 1-?ard

EXPL. shelter under the-ground 
"There is a shelter under the ground"

Example (32) fì ktāb Cala ț̣awleh

EXPL. on the-table

"There is a book on the table"

In the previous examples, the expletive $f i$ is used to fill a syntactic position. This dummy $f i$ can be negated by inserting the split-morpheme " $m \bar{a} . .$. s" before it, where the suffix $-\check{s}$ is optional (Palva, 2004, p. 232); Examples (33)-(34) become as follows:

Example (33) $m \bar{a} f i(\breve{s})$ maldza? taḥt l-rard

NEG. EXPL. shelter under the-ground

"There is no shelter under the ground"

Example (34) $m \bar{a} f \grave{i}(\check{s})$ ktāb sala țțawleh

NEG. EXPL. on the-table

"There is no book on the table"

The nominal sentence and the negation in JA. A nominal sentence in Arabic is the sentence in which "the subject normally precedes the predicate" (Aziz, 1989, p. 12). The copulas are the linking verbs which link the subject and the predicate. In Arabic, a nominal sentence has no copula in the present, whereas in the past, the copula $k \bar{a} n$ "was" is added.

In JA, sentences with no copulas are negated with miš. This negative particle is "regularly used to negate the predicate of a nominal clause, an individual word, a prepositional phrase, or an adverb" (Palva, 2004, p. 231); for further explanation, here are some examples (see Examples (35)-(36)).

Example (35) Sammān ḥilwah

Gammān beautiful

"Amman is beautiful” (SawāYi, 2009, pp. 19-20)

To negate the predicates in Example (35) the negation marker miš is inserted before them, making the following structures:

Example (36) Gammān miš ḥilwah

Yammān NEG. beautiful

"Amman isn't beautiful" (SawāCi, 2009, pp. 19-20)

Sentences containing the copula $k \bar{a} n$, on the other hand, are negated by $m \bar{a}$ with attention to the person, gender and number agreements with the subject. For further explanation, see Examples (37)-(38):

Example (37) hī kānat kwaysih

3rd sg.M. COP. good

"She was good"

Example (38) hummu $m \bar{a}$ kānūš bilbēt

3rd pl. NEG. COP. at-home

"They were at home"

The verb phrase and negation in JBPA. The verbal sentences and negation in JBPA. The past/perfect and the present/imperfect in JBPA were not preserved. The imperfect aspect was interchangeably used for the past and the present tense. For the listener, this lack of inflection for tense can be compensated by context (e.g., 
adverbs of time). Moreover, the tense/aspect might be expressed by the use of the JBPA copula $f i$. Examples (39)-(43) illustrate more:

Example (39) ?ana binam sā dās

1st SG. slept o'clock eleven

"I sleep at eleven o'clock"

Context: The participant is asked "What time did you sleep yesterday?"

Example (40) bi-awwal huwwa momgin birōh dubai bādēn huwwa izi zōrdan

First 1st SG. might go Dubai then 3rd SG.M come Jordan

"First, they went to Dubai, then they came to Jordan"

Context: Participant is asked "How did Bengalis come to Jordan?"

Example (41) ?ana zawwaz talata sana

1st sg. marry three year

"I got married three years ago"

Context: Participant is asked "When did you get married?"

Example (42) banāt $f i$ zawwaz kullu ?umrā arbā tās

girls COP. marry 3SG.F. all age fourteen

"The girls in Bangladesh get married at the age of fourteen"

Context: The participant is asked "At what age do Bengali girls get married?"

Example (43) masna waditu kullu umal masna bilbahrul mayet

Factory send-3rd SG.M workers fatory in Dead-Sea

"The factory sent all the workers to the Dead Sea"

Context: The participant is asked "Have you ever been on a picnic"

Bakir (2010, p. 206) stated that the existence of some inflections on some verbs should not be taken as an inflection of the imperfect verb (as stable), which is the case for our study.

Regarding negation, the JA negative markers $m \bar{a} f \hat{\imath}(\hat{s})$ and $m \bar{a}$ were interchangeably used to negate both the perfect and imperfect verbs in JBPA. However, to distinguish the first form of the negation from other types of negation (e.g. progressive, copula, and expletive negation), the author considered the first structure $m \bar{a} f i(\hat{s})$ as one particle (henceforth, māfîi $(\hat{s})$ rather than two separate particles (as in other studies, e.g., Avram, 2010; Næss, 2008). See Examples (44)-(46):

Example (44) ?ana māfǐs rūḥ maqān tāni

1st SG. NEG. go. PER. place second

"I didn't go to any other place"

Context: Participant is asked "have ever been to a country other than Jordan?"

Example (45) napar Bengali mā bilāb lēs asan huwwa kullu īzi hon sokul

One person Bengali. NEG. play.IPF. why because 3SG. all come here work

"Bengalis don't play here, because we come here only for work"

Context: Participant is asked "What kinds of games do you and your friends play here?"

Example (46) ana $m \bar{a}$ bišūp, huwwe napar šūp

1st SG. NEG. see 3rd SG. M. person see 
"I don't see him; my friends see him"

Context: Participant is asked 'What does your friend work in Madīnatil Hasan?'

In addition, the imperative verbs in the JBPA were not inflected for person, gender or number. The JA negative particle $l \bar{a}$ was not attested in the JBPA; rather, the particle $m \bar{a} f i(\breve{s})$ was used. Example (47) explains more:

Example (47) inte māfǐ̀ yinām asan ?ana fĩ sogul

2nd SG. NEG. sleep. IMP. because EXPL. work

"Don't sleep now because we have some work to do"

Context: Participant is asked "If your friend wants to sleep, but you have some work, and want him to help you, what do you tell him?"

Furthermore, the pseudo-verb bidd+, which is used as a future marker in JA, was attested in the JBPA; yet no consistent distinction for person, gender, and number was noticed. To negate the pseudo-verb, the participants used the negative marker $m \bar{a}$ (see Examples (48)-(49)):

Example (48) inta biddu rūh Banglades?

1st SG. will go Bangladesh?

"Will you go to Bangladesh?"

Example (49) la ana ma biddu rūh sūdiah asan fisa mā fǐs̆

No 1st SG. NEG. will go Saudi Arabia because visa NEG. EXPL.

"I won't go to Saudi Arabia because I have no visa"

Context: The participant is asked "Will you go to Saudi Arabia?"

In addition, the speakers did not preserve the JA progressive aspect; they, instead, used $f i$, and negated it by $m \bar{a}$. Examples (50)-(51) clarify this:

Example (50) Sēf, mā biddu sōt, bēbi fi nōm hassa.

Sēf NEG. want sound, bēbi TAM. sleep now

"Sēf, don't make noise! The baby is sleeping now"

Context: Participant is asked "What do you tell Sēf if he is making noise and your son wants to sleep?"

Example (51) ida ana $m \bar{a}$ fì sokul, ?ana bisāid huwwa mā fi muskilah

If 1st SG. NEG. TAM. work, 1st SG. help 3SG.M NEG. NEG. problem

"if I'm not working, I help him"

Context: The participant is asked "If your friend needs your help and you are free, do you help him out?"

With reference to the JA modal auxiliary läzim, the author has found that the JBPA speakers used it only for expressing necessity. The auxiliary momkin, however, was fully preserved in the JBPA. Examples (52)-(54) make this clearer:

Example (52) Pana bilbēt īzi momgin sā sitta sā tamanya īzi [expressing possibility]

1SG. home come may o'clock six o'clock eight come

"I might come back home at six or eight o'clock"

Context: The participant is asked "what time do you come back home?"

Example (53) huwwa momkin rūh šwaya mā fĩ muskila [expressing permission] 
3rd SG. may go little NEG. EXPL. problem

"He may go out for a while, no problem"

Context: The participant is asked "do you [a manager] allow a worker to take a five-minute rest?"

Example (54) Pana mudīr sarlu tamānya sana kēp maratu lāzim maw3ūd [expressing necessity]

1st SG. manager factory for eight year how his-wife should existed

"I've been the production manager for eight years; my wife should be here"

Context: The participant is asked "Is your wife in Jordan?"

The expletive $f i$ was frequently seen in the data. The negation of expletive $f i$ by the JA negative marker $m \bar{a}$ was also attested in the JBPA (see Examples (55)-(56)).

Example (55) Banglades $m \bar{a} f i$ dajman sogul bas hōn lagetu dajman sokul

Bangladesh NEG. EXPL. always work but here found. always work

"There is no work in Bangladsh, but here there is a plenty of work"

Context: Participant is asked "why do you come to Jordan?"

Example (56) Banglades o hōn same-same $m \bar{a}$ fĭs faruk bas swajja faruk

In-Bangladesh and here same-same NEG. EXPL. difference only little difference

"There is no difference between Bangladesh and Jordan, only little difference"

Context: Participant is asked "which is more expensive, Jordan or Bangladesh?"

Negation of verbless sentences. One of the main characteristics of pidgins is the absence of copulas. However, the participants used the particle $f i$ as a copula for both the past and present (see Examples (57)-(59)).

Example (57) kalām arabi hada kullu fì mālum

Speech arabic this all COP. understood.

"Arabic language is familiar to me"

Context: The participant is asked "Can you speak Arabic well?"

Example (58) ? ana umur $f i$ talatin sana

1 st SG. COP. thirty year

"My age is thirty years"

Context: The participant is asked "How old are you?"

Example (59) Pana $f i$ bēbi $f i$ rugūb tajāra Pana $f i$ kaf bas hassa kuwjes

1st SG COP. baby COP. riding plane 1st SG COP afraid but now good

"When I was a child, I was afraid of planes but now it's ok"

Context: Participant is asked "Do you fear planes?"

To negate copulas, the JBPA speakers used $m \bar{a}$ and $m u s ̌$ for both past and present as in Examples (60)-(61).

Example (60) awwal $m \bar{a}$ fĩs gāli bas hassa kullu fĩ gāli

First NEG. expensive now every expensive

"In the past, life wasn't expensive; now it's expensive"

Context: Participant is asked "is life expensive in Jordan?"

Example (61) hunak fulūs muš kuwajes bes hon fĩ šwai kuwajes

There mony NEG. good but here EXPL. little good 
"The salaries there are not good, but in Jordan they are a little bit better"

Context: The participant is asked "where do get more money, in Jordan or in Bangladesh?"

\section{Conclusions}

This article investigated the JBPA features of the phonology, verbal system, and negation of the JBPA against those of the JA to find out if the former is a pidgin. The study revealed that the phonology in the JBPA was reduced and simplified, i.e., some consonants were either lost or have undergone a shift from the lexifier JA (e.g., the velar $/ \mathrm{x} /$ was pronounced as $/ \mathrm{k} /$, and $/ \mathrm{g} / \mathrm{as} / \mathrm{k} /$ or $/ \mathrm{g} /$ ); these features are also attested in other Arabic-lexified pidgins (Watson, 1989; Avram, 2010; Miller, 1993; Næss, 2008).

Regarding the verbal system, we have clearly seen that the JBPA verb was invariant and unmarked for person, gender, and number. The JBPA speakers neither marked the aspect in present nor in past; besides, they did not inflect the tense/aspect for person, gender, and number. The subjects never seemed to distinguish the perfect and imperfect; they frequently borrowed the 3rd SG.M. imperfect form to express both perfect and imperfect. Furthermore, we have noticed that in the JBPA speakers expressed future tense either by the use of the adverbs of time that denote futurity, or by inserting the so-called pseudo-verb bidd + , with the latter not being inflected for person, gender, and number.

With regard to the mood, the JA imperative structure was attested in the JBPA, yet the distinction for number was lost. Considering the modals, läzim was "partially preserved" in the JBPA, i.e., the JBPA speakers used it only to express obligation. On the other hand, the modal momkin was "fully preserved" in the JBPA.

When it comes to the JBPA negative markers, the author can basically divide them into three kinds: The first is the "polyfunctional" negative particle $m \bar{a}$, which was used for the negation of perfect and imperfect, the particle $f \bar{l}$ as a copula, a progressive marker and as expletive. The second negative marker is $m \bar{a} f(\tilde{l}(\breve{s})$ which was used to negate imperatives (sometimes perfect and imperfect). The last one is miš which was used with the nominal sentences that lack copulas.

In light of what has been introduced, the author can conclude that the JBPA variety cannot be considered as a "stabilized or conventionalized pidgin"; rather, it can be classified under the first stages of pidgins, as a "pre-pidgin" or "incipient pidgin". Moreover, we have seen that the study was based only on two languages (Bengali and JA), which goes against the claim that pidgins form only when there are several languages in contact (two or more). Actually, the period required for two languages to form a pidgin is not, and should not, be defined.

\section{Recommendations}

Since the current study was restricted to some areas of the JBPA, the author recommended some aspects which can be taken into consideration in later relevant researches: (1) Since this study was conducted with reference to only one substrate language, the author highly recommended that further researches be made upon other substrate languages in Jordan; (2) Due to the restricted accessibility to the women, the author was not able to include them in the study, which can be taken into account in later studies; and (3) considering the JBPA linguistic features, this study investigated them with regard to phonology, verb phrase, and negation. Some other areas in JBPA, such as the noun phrase, the numerals, reduplication, and pragmatic functions, are also recommended to be studied. 


\section{References}

Akande, A. T. (2010). Is Nigerian pidgin English English?. Dialectologia Et Geolinguistica, 18(1), 3-22.

Avram, A. (2010). An outline of romanian pidgin Arabic. Journal of Language Contact, 3, 20-38.

Aziz, Y. (1989). A contrastive grammar of English and Arabic. Mosul: University of Mosul.

Bakir, M. J. (2010). Notes on the verbal system of gulf pidgin Arabic. Journal of Pidgin \& Creole Languages, 25(2), 201-228.

Bickerton, D. (1990). Language and species. Chicago: University of Chicago Press.

Cantineau, J. (1946). Les Parlers Arabes du Hōrān (The dialects of Hōrān). Paris: Librairie C. Klincksieck.

Decamp, D. (1977). The development of Pidgin and Creole languages (pp. 3-20). A. Valdman (Ed.). Bloomington: Indiana University Press.

Ellis, R. (1985). The study of second language acquisition. Oxford: Oxford University press.

Ferguson, C. A. (1971). Absence of copula and the notion of simplicity: A study of normal speech, baby talk, foreigner talk and pidgins. In D. Hymes (Ed.), Pidginization and creolization of languages (pp. 141-150). Cambridge: Cambridge University Press.

Habash, N. Y. (2006). Arabic and its dialects. Multilingual, 17(5), 12-15.

Hall, R. A. (1966). Pidgin and Creole languages. Ithaca: Cornell University Press.

Herin, B. (2010). The dialect of Salt. In L. Edzard \& R. Jong (Eds.), Encyclopedia of Arabic language and linguistics on-line. Leiden: Brill.

Holm, J. (2000). An introduction to pidgins and Creoles. Cambridge: Cambridge University Press.

Huber, M. (1999). Ghanaian pidgin English in its west African context: A sociohistorical and structural analysis. Amsterdam: J. Benjamins.

Hymes, D. (1971). Pidginization and creolization of languages. Cambridge: Cambridge University Press.

Jarad, N. (2012). The origin and development of expletive $f \grave{\imath}$ in Syrian Arabic. International Journal of Academic Research, 4(4), $127-136$

Kachru, Y. (2006). Hindi. Amsterdam: John Benjamins Pub. Co..

Leechman, D., \& Hall, R. A. (1955). American Indian pidgin English: Attestations and grammatical peculiarities. American Speech, $30(3), 163$.

McLoughlin, L. J. (1982). Colloquial Arabic (Levantine). London: Routledge and Kegan Paul.

McMahon, M. S. (1994). "Pidgins and Creoles": Understanding language change (pp. 253-283). Cambridge: Cambridge University Press.

Miller, C. (1993). Restructuration Morpho-Syntaxique en Juba-Arabic et Ki-Nubi: à propos du débat universaux/substrat et superstrat dans les études creoles (Morpho-syntactic restructuring in Jub-Arabic and Ki-Nubi: A debate about universals/substrate and superstrate in Creole studies). MASGELLAS Nouevelle Serie, 5, 137-174.

Miller, C. (2002). The relevanc of Arabic-based Pidgins-Creoles for Arabic linguistis (pp. 7-46). In G. Mansur \& M. Doss (Eds.), Al-Lugha. Cairo: Arab Development Center.

Næss, U. G. (2008). Gulf pidgin Arabic: Individual strategies or a structured variety? A study of some features of the linguistic behaviour of Asian migrants in the Gulf countries (M.A. thesis, University of Oslo).

Nichols, P. (2004). Creole languages: Forging new identities. In E. Finegan \& J. R. Rickford (Eds.), Language in the USA themes for the twenty-first Century (pp. 133-136, 145-152). New York: Cambridge University Press.

Owens, J. (1997). Arabic-based pidgins and creoles. In S. Thomason (Ed.), Contact languages - A wider perspective (pp. 125-172). Amsterdam: John Benjamins Publishing Company.

Palva, H. (2004). Negation in the dialect of Es-Salt, Jordan: Approaches to Arabic dialects. A collection of articles presented to Manfred Woidich on the Occasion of his Sixtieth Birthday, Leiden.

Patrick, P. (2004). Pidgin and Creole languages: Origins and relationships. Retrieved from http://privatewww.essex.ac.uk/ patrickp/Courses/PCs/IntroPidginsCreoles.htm

Roberts, S. J., \& Bresnan, J. (2008). Retained inflectional morphology in pidgins: A typological study. Linguistic Typology, 12(2), 269-302.

Romaine, S. (1988). Pidgin and Creole languages. London: Longman.

SawāYi, M. (2009). Al- Garabiah Al-Ma ḥkiah fil Pordon (The spoken Arabic in Jordan). Jordan: Jadara lilkitab Al- -alami.

Schumann, J., \& Stenson, N. (1974). New frontiers in second language learning. Rowley, Massachusetts: Newbury House.

Siegel, J. (2009). Chinese pidgin English in southeastern Australia: The notebook of Jong Ah Siug. Journal of Pidgin and Creole languages, 24(2), 306-337. 
Smart, J. R. (1990). Pidginization in Gulf Arabic: A first report. Anthropological linguistics, 32, 83-118.

Swann, J., Deumert, A., Lillis, T., \& Mesthrie, R. (2004). A dictionary of sociolinguistics. Edinburgh: Edinburgh University Press. Tosco, M. (1995). A pidgin verbal system: The case of Juba Arabic. Anthropological Linguistics, 37(4), 423-459.

Valdman, A. (1981). Haitian Creole-English-French dictionary. C. Roberts, S. Yoder, \& Y. Joseph (Eds.). Bloomington IN: Indiana University, Creole Institute.

Vanhove, M., Miller, C., \& Caubet, D. (2009). The grammaticalisation of modal auxiliaries in Maltese and Arabic vernaculars of the Mediterranean area. Empirical Approaches to Language Typology, 44, 325-362.

Vicente, V. S. (2007). English-based pidgins and Creoles: From social to cognitive hypotheses of acquisition. Revista Virtual de Estudos da Linguagem - ReVEL, 5(9). Retrieved from www.revel.inf.br

Watson, R. L. (1989). An introduction to Juba Arabic. Occasional Papers in the Study of Sudanese Languages, (6), 95-117. 